in vivo $32: 745-752(2018)$

doi:10.21873/invivo.11303

\title{
Partial Protection of Paclitaxel-induced Neurotoxicity by Antioxidants
}

\author{
YAEKO HARA $^{1,2^{*}}$, HIROSHI SAKAGAMI $^{2 *}$, HAIXIA SHI ${ }^{2,4}$, TOMOYUKI ABE $^{3}$, \\ NOBUAKI TAMURA ${ }^{3}$, HIROSHI TAKESHIMA ${ }^{3}$, NORIO HORIE ${ }^{5}$, \\ TAKAHIRO KANEKO ${ }^{5}$, HIROSHI SHIRATSUCHI ${ }^{1,2}$ and TADAYOSHI KANEKO ${ }^{1}$ \\ ${ }^{1}$ Department of Oral Maxillofacial Surgery, Nihon University School of Dentistry, Tokyo, Japan; \\ ${ }^{2}$ Meikai University Research Institute of Odontology and ${ }^{3}$ Division of Geriatric Dentistry, \\ Meikai University School of Dentistry, Saitama, Japan; \\ ${ }^{4}$ Department of Traditional Chinese Medicine, Shanghai Ninth People's Hospital, \\ Shanghai Jiatong University School of Medicine, Shanghai, P.R. China; \\ ${ }^{5}$ Department of Oral and Maxillofacial Surgery, Saitama Medical Center, \\ Saitama Medical University, Saitama, Japan
}

\begin{abstract}
Background/Aim: In order to search for substances that reduce the neurotoxicity of paclitaxel, the sensitivity of differentiated rat neuronal PC12 cells to paclitaxel was compared to that of malignant and nonmalignant cells, and the extent to which four antioxidants can alleviate paclitaxel-induced neurotoxicity was investigated. Materials and Methods: Viability of cells was determined by the MTT method. Cytotoxicity was evaluated as the concentration that reduced cell viability by $50 \%\left(C C_{50}\right)$. Tumor specificity of paclitaxel was determined as the ratio of $\mathrm{CC}_{50}$ against non-malignant cells to that against malignant cells. Results: Paclitaxel was three-fold more cytotoxic towards human oral squamous cell carcinoma cell lines (Ca9-22, HSC-2, HSC-3. HSC-4) than human normal epithelial and mesenchymal (human gingival fibroblast, human periodontal ligament fibroblast, human pulp cell) normal cells, confirming its antitumor potential. However, paclitaxel at as low a concentration as $5 \mathrm{ng} / \mathrm{ml}$ significantly reduced neurite formation in nerve growth factor-induced differentiated PC12 cells, although complete killing of cells was not achieved even at 2,000-fold higher concentration (10
\end{abstract}

This article is freely accessible online.

*These Authors contributed equally to this study.

Correspondence to: Hiroshi Sakagami, Meikai University Research Institute of Odontology (M-RIO), Sakado, Saitama 350-0283, Japan. Tel: +81 492792758, +81 492792787. Fax: +81 492855171, e-mail: sakagami@dent.meikai.ac.jp

Key Words: Neurotoxicity, anticancer drug, differentiation stage, PC12, NGF. $\mu M)$. Paclitaxel-induced neurotoxicity was enhanced with the prolongation of incubation time and reduction of inoculation cell density. Four antioxidants, namely docosahexaenoic acid, acetyl-L-carnitine hydrochloride, $N$-acetyl-L-cysteine and sodium ascorbate, only partially protected PC12 cells from paclitaxel-induced toxicity. Conclusion: The present study suggests the involvement of both oxidative and other mechanisms in paclitaxel-induced neurotoxicity.

Paclitaxel is an anticancer drug that inhibits calcium-induced depolymerization of tubulin and thus blocks the progression of mitosis (1). It is clinically applied for the treatment of ovarian, breast, stomach and non-small cell lung cancer $(2,3)$. When used clinically, it causes severe side-effects such as leucopenia. thrombocytopenia, neutropenia and fatigue (4) and anorexia and constipation (5). Patients who received platinum treatment with a taxane were more likely to experience grade 2 to 4 neuropathy (6). Paclitaxel has been reported to induce oxidative stress in liver (slight, but no significant decrease in glutathione in liver) (7). Considering many beneficial effects of antioxidants under optimal conditions (usually achieved by adopting lower doses that stimulate growth) $(8,9)$, prevention of chemotherapeutic drug-induced neurotoxicity by antioxidants has been actively studied in recent years $(10,11)$.

In order to search for substances that reduce neurotoxicity induced by paclitaxel, we first investigated whether nerve growth factor (NGF)-induced differentiating rat neuronal cells (used as neuron model) are also very sensitive to paclitaxel, like malignant cells. The possible protective activity of four antioxidants, docosahexaenoic acid (DHA), acetyl-L-carnitine hydrochloride (ALC), $\mathrm{N}$-acetyl-L-cysteine (NAC) and sodium ascorbate, against neurotoxicity of paclitaxel was then investigated. 


\section{Materials and Methods}

Materials. The following chemicals and reagents were obtained from the indicated companies: Dulbecco's modified Eagle's medium (DMEM), human recombinant NGF, dimethyl sulfoxide (DMSO) and paclitaxel from Wako Pure Chemical Ind., Ltd. (Osaka, Japan); fetal bovine serum (FBS), 3-(4,5-dimethylthiazol-2-yl)-2,5diphenyltetrazolium bromide (MTT) and doxorubicin from SigmaAldrich Inc. (St. Louis, MO, USA); 5-fluorouracil (5-FU) from Kyowa (Tokyo, Japan); docetaxel from Toronto Research Chemicals (Toronto, Canada); gefitinib from LC Laboratories ${ }^{\circledR}$ (PKC Pharmaceuticals, Inc., Woburn, MA, USA); DHA, ALC, NAC, sodium ascorbate (vitamin C) from Tokyo Chemical Industry Co., Ltd (Tokyo, Japan). 96-Microwell plates were purchased from Techno Plastic Products AG (Trasadingen, Switzerland).

Cell culture. PC12, a cell line derived from a pheochromocytoma of the rat adrenal medulla (12), was purchased from Riken Cell Bank (Tsukuba, Japan) and cultured in DMEM supplemented with $10 \%$ heat-inactivated FBS, 100 units/ml, penicillin $\mathrm{G}$ and $100 \mu \mathrm{g} / \mathrm{ml}$ streptomycin under a humidified $5 \% \mathrm{CO}_{2}$ atmosphere. We previously confirmed that PC12 cells proliferated to a slightly higher cell density in DMEM than in mixed culture medium (DMEM+Ham12) and approximately 2-fold higher utilization rate of glutamine and essential amino acids was observed in DMEM (13).

Human normal oral mesenchymal cells [human gingival fibroblast (HGF), human periodontal ligament fibroblast (HPLF) and human pulp cell (HPC)], established from the first premolar tooth extracted from the lower jaw of a 12-year-old girl (14), and human oral squamous cell carcinoma (OSCC) cell lines [Ca9-22 (derived from gingival tissue;HSC-2, HSC-3, HSC-4 (derived from tongue)], purchased from Riken Cell Bank, were cultured at $37^{\circ} \mathrm{C}$ in DMEM supplemented with $10 \%$ heat-inactivated FBS and antibiotics. Human normal oral epithelial cells (primary gingival epithelial cell, HGEP) (CELLnTEC Advanced Cell Systems AG, Bern, Switzerland) were grown in CnT-PR medium (15).

Induction of differentiation toward neurons. Since differentiating PC12 cells are easily detached by suction, and NGF-treated cells secrete growth-promoting factors, we adopted the following overlay method, without medium change. PC12 cells were inoculated at 3,125-25,000 cells $/ \mathrm{cm}^{2}$ and incubated in regular culture medium (DMEM+10\% FBS) for 1 day to achieve complete cell adherence. After replacing the

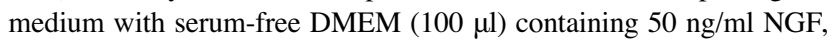
cells were incubated for 3 days to induce partial differentiation of cells. To induce more differentiated cells, cells were overlaid with $50 \mu \mathrm{l}$ of fresh serum-free medium containing $100 \mathrm{ng} / \mathrm{ml} \mathrm{NGF}$ and incubated for a further 2 days. Differentiated cells were defined as cells in which the extended neurites exceeded the longest diameter of each cell, assessed under light microscopy (EVOSfl; ThermoFisher Scientific, Waltham, MA, USA) [described in Figure 1A of (16)].

Cytotoxicity assay. PC12 cells were pretreated with NGF as described above. Human OSCC and normal oral cells were inoculated at $2.5 \times 10^{3}$ cells $/ 0.1 \mathrm{ml}$ in a 96-microwell plate. After 48 $\mathrm{h}$, the medium was replaced with $0.1 \mathrm{ml}$ of fresh medium containing different concentrations of paclitaxel. Cells were incubated further for $48 \mathrm{~h}$ and the relative viable cell number was then determined by the MTT method (13). The MTT concentration was reduced from $0.2 \mathrm{mg} / \mathrm{ml}$ to $0.1 \mathrm{mg} / \mathrm{ml}$ in the experiments with neuronal cells,
Table I. Cytotoxicity of paclitaxel against differentiated PC12, nonmalignant and malignant oral cells. Differentiated rat PC12 cells (day 5) inoculated at different density $\left(3125-25000 \mathrm{cells} / \mathrm{cm}^{2}\right)$, human normal epithelial (HGEP) and mesenchymal cells [human gingival fibroblast $(H G F)$, human periodontal ligament fibroblast (HPLF), human pulp cell $(H P C)]$, and human oral squamous cell carcinoma cell lines derived from gingiva (Ca9-22) and tongue (HSC-2, HSC-3, HSC-4) were treated for 24 or $48 \mathrm{~h}$ with 0.005-50 $\mathrm{MM}$ paclitaxel, and the relative viable cell number was determined by MTT method and the 50\% cytotoxic concentration $\left(C_{50}\right)$ was determined. Each value represents mean from six determinations.

\begin{tabular}{lcccc}
\hline & & $24 \mathrm{~h}$ & \multicolumn{2}{c}{$48 \mathrm{~h}$} \\
\cline { 3 - 4 } Cells & $\begin{array}{c}\text { Inoculated } \\
\text { cells/cm }\end{array}$ & $\begin{array}{c}\mathrm{CC}_{50} \\
(\mu \mathrm{M})\end{array}$ & $\begin{array}{c}\mathrm{CC}_{50} \\
(\mu \mathrm{M})\end{array}$ & $\mathrm{TS}$ \\
\hline Differentiated PC12 & 3125 & 28.2 & 29.8 & $>5960$ \\
& 6250 & 34.5 & 27.0 & $>5400$ \\
& 12500 & 35.5 & 21.7 & $>4340$ \\
HGEP & 25000 & $>50$ & 17.3 & $>3460$ \\
HGF & & 46.6 & 34.8 & $>6960$ \\
HPLF & & $>50$ & 39.4 & $>7800$ \\
HPC & & $>50$ & $>50$ & $>10000$ \\
Ca9-22 & & $<50$ & $>50$ & $>10000$ \\
HSC-2 & & $<0.005$ & $<0.005$ & \\
HSC-3 & & $<0.005$ & $<0.005$ & \\
HSC-4 & & 18.8 & $<0.005$ & \\
\hline
\end{tabular}

TS: Tumor specificity.

considering their higher sensitivity to MTT. The relative viable cell number was determined by the absorbance of the cell lysate at $560 \mathrm{~nm}$, using a microplate reader (Infinite F $50 \mathrm{R}$; TECAN, Kawasaki, Japan). Control cells were treated with the same amount of DMSO and the cell damage induced by DMSO was subtracted from that induced by paclitaxel. The concentration of compound that reduced the viable cell number by $50 \%\left(\mathrm{CC}_{50}\right)$ was determined from the dose-response curve and the mean value of $\mathrm{CC}_{50}$ for each cell type was calculated from six determinations.

Tumor specificity of paclitaxel was determined as the ratio of $\mathrm{CC}_{50}$ against non-malignant cells to that against malignant cells.

Neuroprotection assay. Control (referred to as day 0), day 3 and day 5 cells were overlaid with $50 \mu 1$ of $80 \mathrm{nM}$ paclitaxel (final $20 \mathrm{nM}$ ) (unless otherwise stated) in the presence of increasing concentration of antioxidants, and incubated for $48 \mathrm{~h}$ to determine the viable cell number by MTT method. The percentage decrease of absorbance at $560 \mathrm{~nm}$ induced by $20 \mathrm{nM}$ paclitaxel alone (A\%), antioxidant without paclitaxel at each concentration $(\mathrm{B} \%)$, or combination of $20 \mathrm{nM}$ paclitaxel and antioxidant at each concentration $(\mathrm{C} \%)$ was determined. The protective effect $(\mathrm{PE})$ was calculated using the following equation: $\mathrm{PE}(\%)=\mathrm{A}+\mathrm{B}-\mathrm{C}$.

Statistical treatment. Experimental values are expressed as the mean \pm standard deviation (SD) of six determinants. Statistical analysis was performed using Student's $t$-test. A $p$-value of less than 0.05 was considered significant. 

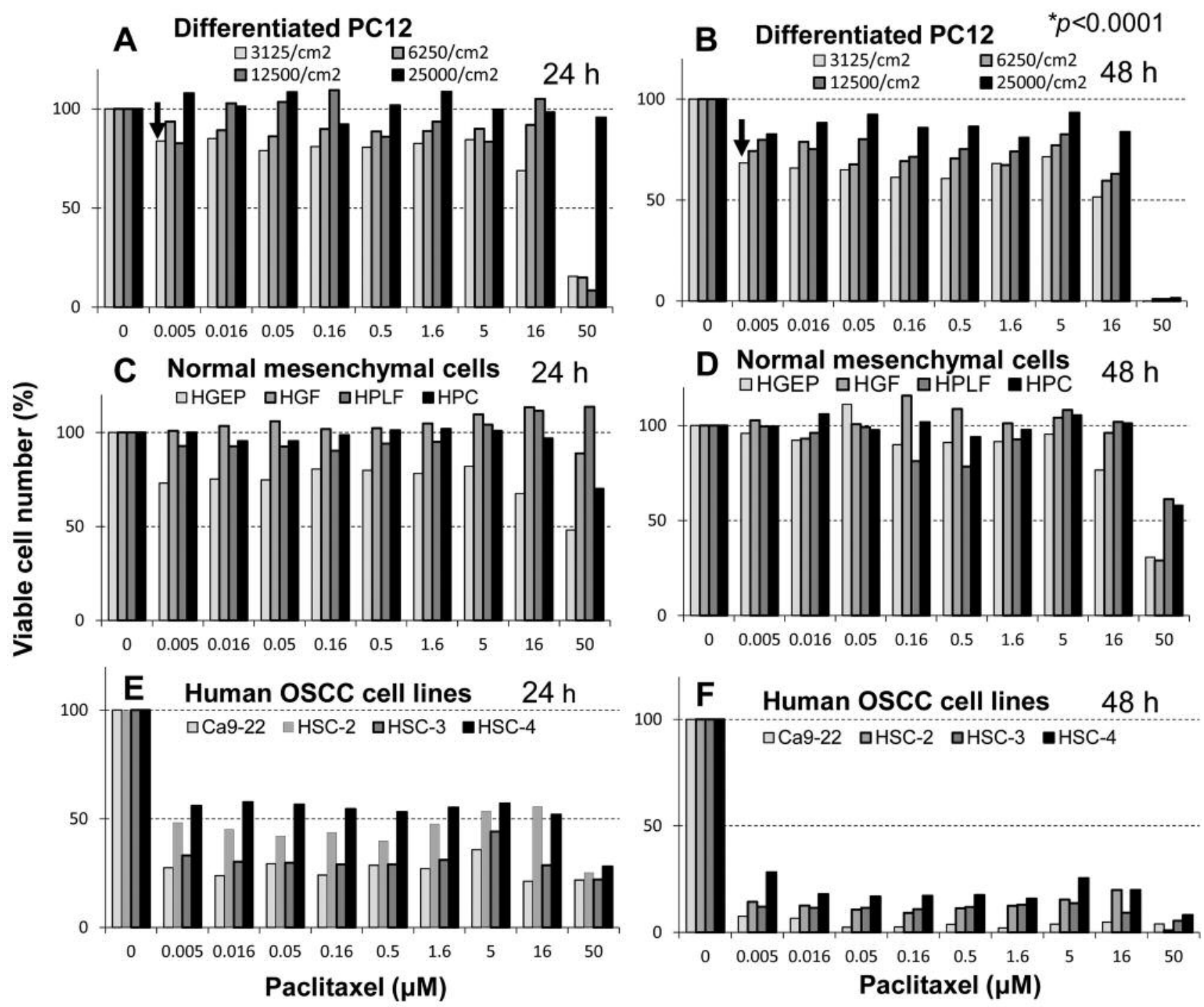

Figure 1. Cytotoxicity of paclitaxel towards rat neuronal cells compared to that towards human non-malignant and malignant cells. Differentiated rat PC12 cells (day 5) inoculated at different density $\left(3,125-25,000\right.$ cells $\left./ \mathrm{cm}^{2}\right)(A, B)$, human normal epithelial (HGEP) and mesenchymal cells [human gingival fibroblast (HGF), human periodontal ligament fibroblast (HPLF), human pulp cell (HPC)] (C, D), and human oral squamous cell carcinoma cell lines derived from gingiva (Ca9-22) and tongue (HSC-2, HSC-3, HSC-4) (E, F) were treated for 24 (A, C, E) or 48 h (B, D, F) with the indicated concentrations of paclitaxel, and relative viable cell number was determined by MTT method. Each value represents the mean from six determinantions. The $50 \%$ cytotoxic concentration $\left(\mathrm{CC}_{50}\right)$ of paclitaxel is listed in Table I.

\section{Results}

Confirmation of tumor specificity of paclitaxel. We first confirmed the tumor-specificity of paclitaxel. Four human OSCC cell lines derived from gingiva ( $\mathrm{Ca} 9-22)$ and tongue (HSC-2, HSC-3, HSC-4), and four human normal oral cells derived from epithelial (HGEP) and mesenchymal tissues (HGF, HPLF, HPC) were incubated with increasing concentrations of paclitaxel $(0-50 \mu \mathrm{M})$, and cell viability was measured by the MTT method after $24 \mathrm{~h}$ and $48 \mathrm{~h}$ (Figure 1). It is apparent that
OSCC cell lines were highly sensitive to paclitaxel as compared with normal cells. The cytotoxic effect of paclitaxel against OSCC cells was increased with prolonged incubation time. Viability of all four OSCC cell lines after $48 \mathrm{~h}$ was below $25 \%$ even at as low a concentration as $5 \mathrm{nM}$ paclitaxel, yielding tumor specificity values of 6,960-10,000 (Table I). Based on these results, paclitaxel showed excellent tumor specificity.

Among normal oral cells, HGEP cells were slightly more sensitive to paclitaxel than mesenchymal cells (HGF, HPLF, HPC), consistent with previous findings (17). 

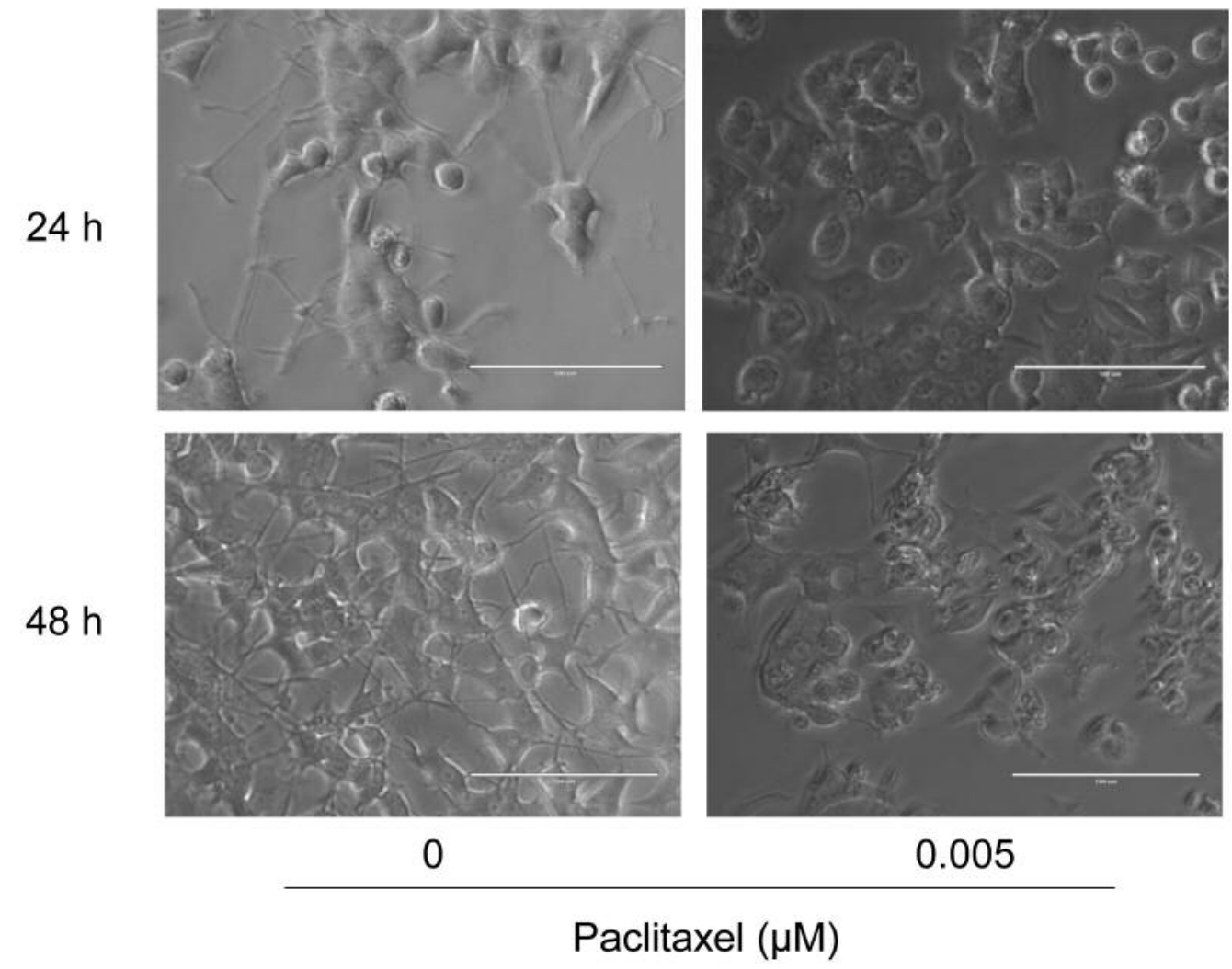

Figure 2. Inhibition of neurite formation by paclitaxel. Differentiated PC12 cells (day 5) were treated for 24 or 48 without or with 5 nM paclitaxel as described in the Materials and Methods section and cell morphology was observed under light microscopy. Bar: $100 \mu \mathrm{m}$.

Inhibition of neurite growth by nanomolar concentration of paclitaxel. Paclitaxel at $5 \mathrm{nM}$ slightly, but significantly $(p<0.0001)$ reduced the viable cell number (indicated by arrows in Figure $1 \mathrm{~A}$ and $\mathrm{B})$. The cytotoxic effect of paclitaxel on differentiated PC12 cells was also increased with prolongation of treatment time (compare Figure 1A and B). The reduction of cell viability was coupled with the loss of neurite formation induced by $5 \mathrm{nM}$ paclitaxel (Figure 2). This phenomenon was observed as early as at $24 \mathrm{~h}$ after treatment regardless of the inoculated cell density (3.1$12.5 \times 10^{3} / \mathrm{cm}^{2}$ ) (Table II), although a slight decrease in neurotoxicity of paclitaxel was observed at higher cell densities (Figure 1A and B).

Taxanes induce cytostatic growth inhibition of differentiated PC12 cells. Docetaxel, analog of paclitaxel, showed cytostatic growth retardation, in similar fashion to paclitaxel, whereas doxorubicin, 5-FU and gefitinib were cytotoxicity $\left(\mathrm{CC}_{50}=44,7,500\right.$ and $32,000 \mathrm{nM}$, respectively) (Figure 3).

Protective effects of antioxidants. All antioxidants showed cytotoxicity at high concentrations. The $\mathrm{CC}_{50}$ of DHA, ALC,
Table II. Induction of neurocytotoxicity by nanomolar concentration of paclitaxel. PC12 cells were induced to differentiate by treatment for 5 days with $50 \mathrm{ng} / \mathrm{ml}$ nerve growth factor and treated for $24 \mathrm{~h}$ without or with $5 \mathrm{nM}$ paclitaxel. The percentage of differentiated cells with neurites was scored by counting at least 100 cells per well. Each value represents mean $\pm S$.D. from six determinantions.

\begin{tabular}{lccc}
\hline $\begin{array}{l}\text { Inoculated } \\
\text { cell density } \\
\left(\times 10^{3} / \mathrm{cm}^{2}\right)\end{array}$ & \multicolumn{2}{c}{$\begin{array}{c}\text { Differentiated cells (\%) } \\
\text { Paclitaxel }\end{array}$} & \\
\cline { 2 - 3 } & $0 \mathrm{nM}$ & $5 \mathrm{nM}$ & $p$-Value \\
\hline 3.1 & $92.0 \pm 3.1$ & $10.3 \pm 6.3$ & $<0.0001$ \\
6.3 & $92.5 \pm 4.5$ & $14.5 \pm 3.1$ & $<0.0001$ \\
12.5 & $90.0 \pm 5.6$ & $19.8 \pm 11.4$ & $<0.0001$ \\
\hline
\end{tabular}

NAC and sodium ascorbate was $0.0061,9.8,6.3$ and $0.33 \mu \mathrm{M}$, respectively (Exp. 1 in Figure 4). These antioxidants slightly stimulated the growth of differentiated PC12 cells at lower concentrations. The maximum growth stimulation (hormesis) by DHA, ALC, NAC and sodium ascorbate was 23, 37, 27 and $12 \%$, respectively (Exp. 2 in Figure 4). 

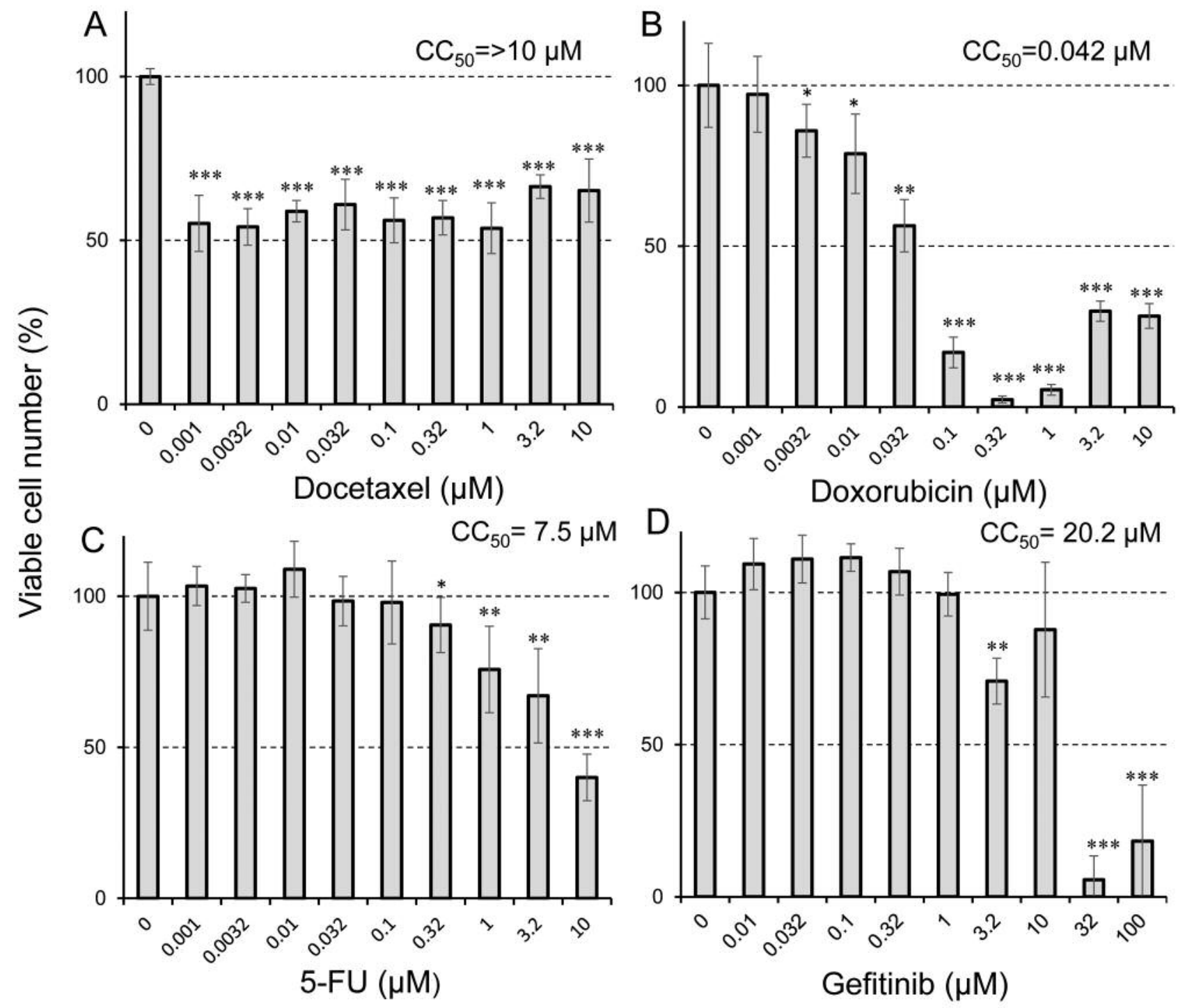

Figure 3. Sensitivity of differentiated PC12 cells to four anticancer drugs. Differentiated PC12 cells (day 5) were treated for 48 h without (control) or with the indicated concentrations of docetaxel $(A)$, doxorubicin (B), 5-fluorouracil (5-FU) $(C)$ and gefitinib $(D)$. Cell viability (\%) was then determined by the MTT method. Each value represents the mean $\pm S$.D. from six determinantions. Significantly different at $* p<0.05, * * p<0.005$ and $* * * p<0.0005$.

We next performed combination experiments with paclitaxel and either one of the antioxidants. Using the data of Figure 4, the degree of protection against paclitaxel-induced neurotoxicity by four antioxidants was calculated (Figure 5). The protective effects of DHA, ALC, NAC and sodium ascorbate were observed at relatively high concentrations for each compound (Exp. 2). The effective concentration of DHA was three orders lower than the other three antioxidants, and protective effects of sodium ascorbate were observed over a wide range from 0.125 to $1 \mu \mathrm{M}$. However, the maximum protective effects of DHA, ALC, NAC and sodium ascorbate were only 41, 27, 34 and 45\%, respectively (Figure 5).

\section{Discussion}

The present study demonstrated that paclitaxel induced neurotoxicity at concentrations comparable to that causing cytotoxicity in malignant cells. Neurotoxicity induced by amyloid- $\beta$ peptides are caused by mitochondrial dysfunction and oxidative stress (18), alteration of metal ion influx (19), endoplasmic reticulum stress (20) and impaired autophagy (21). Amyloid $\beta$-induced neuronal cell death may be partially alleviated by antioxidants (22-24). DHA, ALC, NAC and sodium ascorbate protected from neuronal toxicity, but only partially (Figure 5). This 


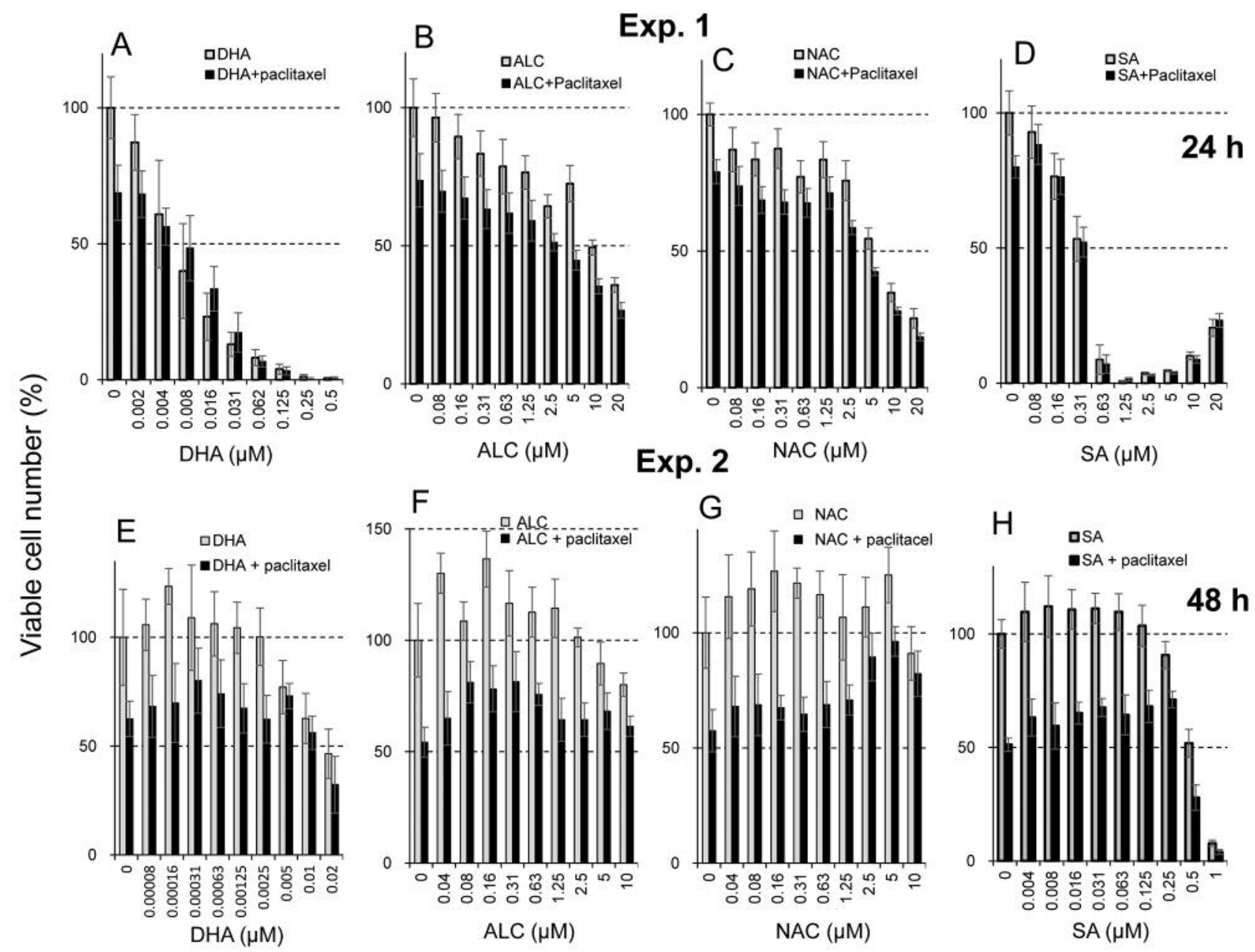

Figure 4. Protective activity of four antioxidants against paclitaxel-induced cytotoxicity in differentiated PC12 cells in two independent experiments (Exp 1: A-D; Exp. 2: E-H). Cells were incubated for $48 \mathrm{~h}$ with $25 \mathrm{nM}$ paclitaxel in the presence of the indicated concentrations of docosahexaenoic acid (DHA) $(A, E)$, acetyl-L-carnitine hydrochloride $(A L C)(B, F), N$-acetyl-L-cysteine $(N A C)(C, G)$, or sodium ascorbate $(S A)(D, H)$. Each value represents the mean $\pm S . D .(n=6)$.

suggests the involvement of both oxidative and other mechanisms in paclitaxel-induced neurotoxicity.

Growth stimulation observed at low doses of toxicants and radiation is known as hormesis $(25)$. We recently reported that hormetic growth stimulation and inhibition of amyloid- $\beta$ aggregation may be involved in the neuroprotection afforded by alkaline extract of the leaves of Sasa senanensis Rehder, available as a group III over-the-counter drug (16). DHA, ALC, NAC and sodium ascorbate showed weak hormetic growth stimulation at low concentrations (Exp. 2 in Figure 5). It remains to be investigated whether the protective effects of antioxidants are due to hormesis, using terminally differentiated neuron cells where growth is stopped.

The protective effect of DHA was observed at three-order lower concentrations than that observed with the other three antioxidants, possibly due to its higher hydrophobicity: $\log \mathrm{P}=6.78$ for DHA vs. -0.15 for ALC, -0.15 for NAC, and -2.86 for sodium ascorbate. It should be noted that the effective range of sodium ascorbate is relatively broader. Elucidation of the protective mechanism of DHA and sodium ascorbate may allow delay of the onset or progression of dementia and neurodegenerative diseases such as Alzheimer's disease (26).

\section{Conflicts of Interest}

The Authors confirm that there are no known conflicts of interest associated with this publication and there was no significant financial support for this work that could have influenced its outcome.

\section{Acknowledgements}

This work was partially supported by KAKENHI from the Japan Society for the Promotion of Science (JSPS) (16K11519). 

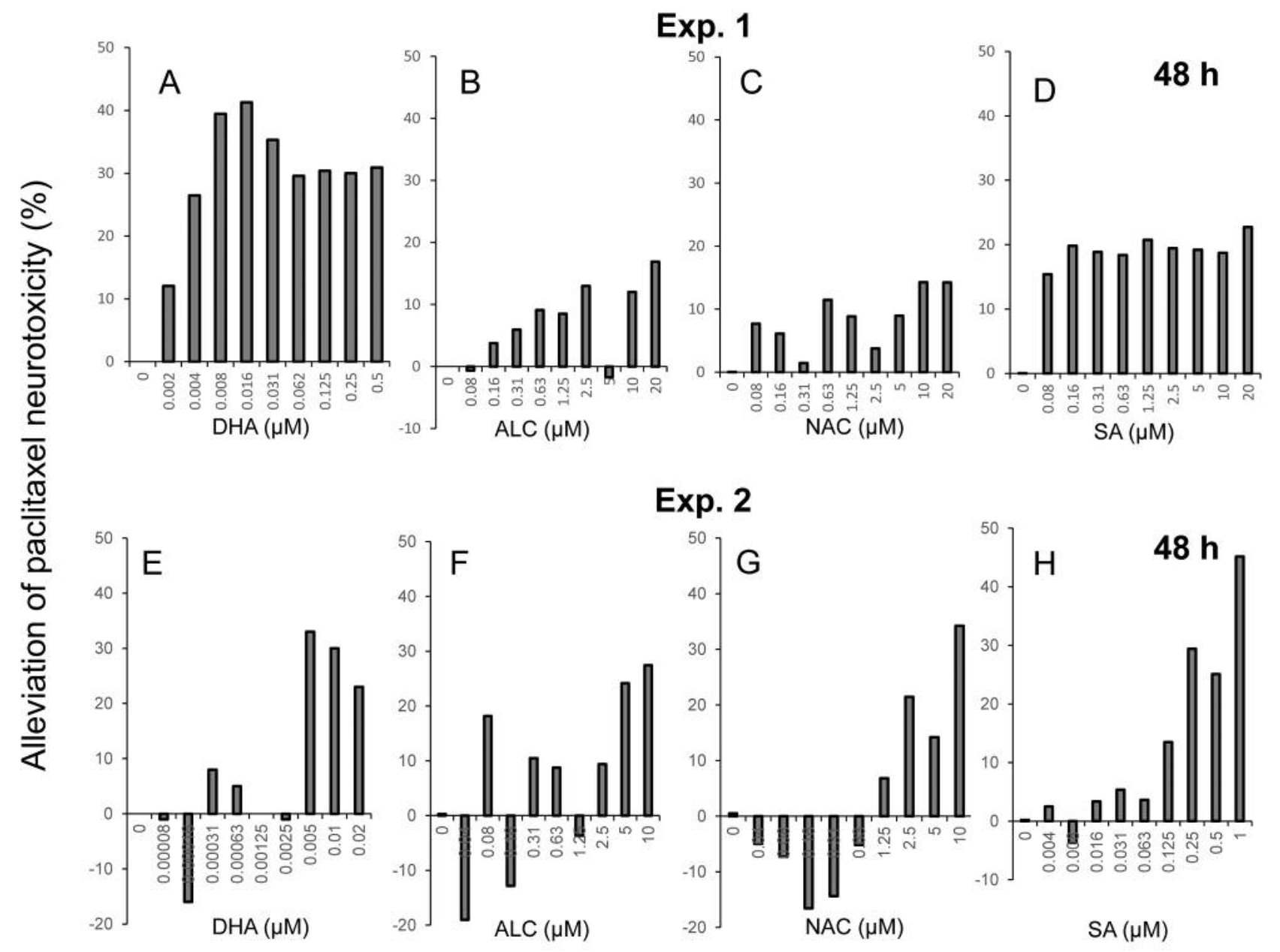

Figure 5. Calculation of alleviation of paclitaxel-induced neurotoxicity by antioxidants. Cells were treated for $48 \mathrm{~h}$ with $25 \mathrm{nM}$ paclitaxel in the presence of the indicated concentrations of docosahexaenoic acid (DHA) (A,E), acetyl-L-carnitine hydrochloride (ALC) $(B, F), N$-acetyl-L-cysteine (NAC) $(C$, $G)$, or sodium ascorbate $(S A)(D, H)$ and the protective effect of antioxidants was calculated as described in the Materials and Methods section.

\section{References}

1 Goodman and Gilman's The Pharmacological Basis of Therapeutics, 13th Edition. Section VIII Pharmacotherapy of Neoplastic Diseases. McGraw Hill pp. 1159 1248, 2018.

2 Rowinsky EK: Paclitaxel pharmacology and other tumor types. Review. Semin Oncol 24(6 Suppl 19): S19-1-S19-12, 1997.

3 Malingré MM, Beijnen JH, Rosing $\mathrm{H}$, Koopman FJ, van Tellingen O, Duchin K, ten Bokkel Huinink WW, Swart M, Lieverst $\mathbf{J}$ and Schellens JH: The effect of different doses of cyclosporin A on the systemic exposure of orally administered paclitaxel. Anticancer Drugs 12(4): 351-358, 2001.

4 Okada K, Hirono S, Kawai M, Miyazawa M, Shimizu A, Kitahata Y, Ueno M, Hayami S, Shimokawa T and Yamaue H: Prospective validation of patient fatigue questionnaire (FACITF) for fatigue assessment in nab-paclitaxel plus gemcitabine therapy. Mol Clin Oncol 8(1): 121-126, 2018.

5 Naito Y, Tamiya A, Tamiya M, Kimura Y, Hamaguchi M, Saijo N, Kanazu M, Tokura S, Shiroyama T, Morisita N, Omachi N,
Suzuki H, Okamoto N, Okishio K, Hirashima T and Atagi S: Efficacy of nanoparticle albumin-bound paclitaxel regimens for relapsed small cell lung cancer: A retrospective analysis. Medicine (Baltimore) 96(35): e7884, 2017.

6 Hershman DL, Till C, Wright JD, Awad D, Ramsey SD, Barlow WE, Minasian LM and Unger J: Comorbidities and risk of chemotherapy-induced peripheral neuropathy among participants 65 years or older in southwest oncology group clinical trials. J Clin Oncol 34(25): 3014-3022, 2016.

7 Pieniążek A, Czepas J, Piasecka-Zelga J, Gwoździński K and Koceva-Chyła A: Oxidative stress induced in rat liver by anticancer drugs doxorubicin, paclitaxel and docetaxel. Adv Med Sci 58(1): 104-111, 2013.

8 Ali-Hasan-Al-Saegh S, Mirhosseini SJ, Ghodratipour Z, SarrafanChaharsoughi Z, Rahimizadeh E, Karimi-Bondarabadi AA, Haddad F, Shahidzadeh A, Mahdavi P, Dehghan AM, Tahernejad M, Shahidzadeh A, Dehghan H, Ghanei A, Lotfaliani M, Weymann A, Zeriouh M, Popov AF and Sabashnikov A: Strategies Preventing contrast-induced nephropathy after coronary angiography: A 
comprehensive meta-analysis and systematic review of 125 randomized controlled trials. Angiology 68(5): 389-413, 2017.

9 Firuzi O, Miri R, Tavakkoli M and Saso L: Antioxidant therapy: current status and future prospects. Review. Curr Med Chem 18(25): 3871-3888, 2011.

10 Cetin D, Hacimuftuoglu A, Tatar A, Turkez H and Togar B: The in vitro protective effect of salicylic acid against paclitaxel and cisplatin-induced neurotoxicity. Cytotechnology 68(4): 13611367, 2016.

11 Ramezani F, Samadi N and Mostafavi-Pour Z: Sequential therapy of breast cancer cell lines with vitamin $\mathrm{C}$ and quercetin improves the efficacy of chemotherapeutic drugs. Nutr Cancer 69(6): 881-891, 2017.

12 Greene LA and Tischler AS: Establishment of a noradrenergic clonal line of rat adrenal pheochromocytoma cells which respond to nerve growth factor. Proc Natl Acad Sci USA 73(7): 2424-2428, 1976.

13 Sakagami H, Suzuki R, Shirataki Y, Iwama S, Nakagawa M, Suzuki H, Tanaka K, Tamura N and Takeshima H: Re-evaluation of culture condition of PC12 and SH-SY5Y cells based on growth rate and amino acid consumption. In Vivo 31(11): 10891095, 2017.

14 Kantoh K, Ono M, Nakamura Y, Nakamura Y, Hashimoto K, Sakagami $\mathrm{H}$ and Wakabayashi $\mathrm{H}$ : Hormetic and anti-radiation effects of tropolone-related compounds. In Vivo 24: 843-852, 2010.

15 Sakagami H, Shimada C, Kanda Y, Amano O, Sugimoto M, Ota S, Soga T, Tomita M, Sato A, Tanuma S, Takao K and Sugita Y: Effects of 3-styrylchromones on metabolic profiles and cell death in oral squamous cell carcinoma cells. Toxicol Rep 2: 1281-1290, 2015 .

16 Sakagami H, Tsuji M, Tomomura M, Masuda Y, Iwama S, Nakagawa M, Suzuki H, Tanaka K, Abe T, Tamura N, Tomomura A, Yokose S, Takeshima H, Natori T, Horiuchi M, Fujisawa T, Kiuchi Y, Oguchi K, Yasui T, Oizumi H and Oizumi T: Protection of differentiating neuronal cells from amyloid $\beta$ peptide-induced injury by alkaline extract of leaves of Sasa senanensis Rehder. In Vivo 32(2): 231-239, 2018.

17 Sakagami H, Okudaira N, Masuda Y, Amano O, Yokose S, Kanda Y, Suguro M, Natori T, Oizumi $H$ and Oizumi T: Induction of apoptosis in human oral keratinocyte by doxorubicin. Anticancer Res 37(3): 1023-1029, 2017.
18 Jazvinšćak Jembrek M, Hof PR and Šimić G: Ceramides in Alzheimer's disease: key mediators of neuronal apoptosis induced by oxidative stress and $A \beta$ accumulation. Oxid Med Cell Longev 2015: 346783, 2015.

19 Wang P and Wang ZY: Metal ions influx is a double-edged sword for the pathogenesis of Alzheimer's disease. Ageing Res Rev 35: 265-290, 2017.

20 Gerakis $\mathrm{Y}$ and Hetz C: Emerging roles of ER stress in the aetiology and pathogenesis of Alzheimer's disease. FEBS J 285(6): 995-1011, 2018.

21 Salminen A, Kaarniranta K, Kauppinen A, Ojala J, Haapasalo A, Soininen and Hiltunen M: Impaired autophagy and APP processing in Alzheimer's disease: The potential role of beclin 1 interactome. Prog Neurobiol J 106-107: 33-54, 2013.

22 Gurer-Orhan H, Karaaslan C, Ozcan S, Firuzi O, Tavakkoli M, Saso L and Suzen S: Novel indole-based melatonin analogues: Evaluation of antioxidant activity and protective effect against amyloid $\beta$-induced damage. Bioorg Med Chem 24(8): 16581664, 2016.

23 Guimarães CC, Oliveira DD, Valdevite M, Saltoratto AL, Pereira SI, França Sde C, Pereira AM and Pereira PS: The glycosylated flavonoids vitexin, isovitexin, and quercetrin isolated from Serjania erecta Radlk (Sapindaceae) leaves protect PC12 cells against amyloid- $\beta 25-35$ peptide-induced toxicity. Food Chem Toxicol 86: 88-94, 2015.

$24 \mathrm{Ai} \mathrm{Z}$, Li C, Li L and He G: Resveratrol inhibits $\beta$-amyloidinduced neuronal apoptosis via regulation of p53 acetylation in PC12 cells. Mol Med Rep 11(4): 2429-2434, 2015.

25 Calabrese EJ: Biphasic dose responses in biology, toxicology and medicine: accounting for their generalizability and quantitative features. Environ Pollut 182: 452-460, 2013.

26 Jouanne M, Rault S and Voisin-Chiret AS: Tau protein aggregation in Alzheimer's disease: An attractive target for the development of novel therapeutic agents. Eur J Med Chem 139: 153-167, 2017 